DOI No: http://dx.doi.org/10.29228/Joh.51303

Authenticity process is conducted by

Makale Türü: Araştırma makalesi

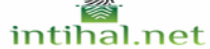

Geliş Tarihi: 06-05-2021

Kabul Tarihi: $19-08-2021$

On-line Yayın: 31-08-2021

Article Type: Research article Submitted: 06-05-2021

Accepted: 19-08-2021

Published Online: 31-08-2021

Atıf Bilgisi / Reference Information

Kimya, O. (2021). 17. Yüzyılda Osmanlı Devleti'nde Meydana Gelen Salgın Hastalıklar, Bunların Neden Olduğu Toplumsal Sarsıntılar ve Göçler. Journal of History School, 53, 2382-2403.

\title{
17. YÜZYILDA OSMANLI DEVLETİ'NDE MEYDANA GELEN SALGIN HASTALIKLAR, BUNLARIN NEDEN OLDUĞU TOPLUMSAL SARSINTILAR VE GÖÇLER
}

\section{$\ddot{O} z$}

\section{Osman KIMYA ${ }^{1}$}

İnsanlık tarihinin başlangıcıyla beraber hastalıklar toplumların baş etmek zorunda olduğu büyük sorunlardan biri olmuştur. Bu hastalıklardan özellikle salgına dönüssen ve bulaşıcı bir hal alanlar, tarihin her döneminde toplumların sosyo-ekonomik, kültürel, askerî ve siyasî durumlarını etkileyen önemli hadiselerden olmuştur. Salgınlar ăgır sonuçlara neden olarak insan ölümlerinin en önemli sebebi arasında gelmektedir. Binlerce ölüme ve sakatlığa sebep teşkil etmiş̦tir. Toplumlar arasındaki etkileşimin artmasıyla birlikte meydana gelen salgınların yayılma hızı da artmıştır. Uzun yıllar geniş bir coğrafyada hüküm süren Osmanlı Devleti bulunduğu coğrafi konum itibariyle geçiş ve ticaret yollarının güzergâhında olması bu durumu daha da tetiklemiştir. Dolayısıyla Osmanlı Devleti pek çok zaman bu salgın hastalıklardan nasibini almış ve bu salgınlarla mücadele etmek zorunda kalmıştır. Bu çalışmada Osmanlı Devleti'nde özellikle 17. yüzyılda yaşanan salgın hastalıklara değinilerek, bu hastalıkların devlette ve toplumda neden olduğu tahribat incelenmeye gayret edilmiştir. Bununla beraber salgınlardan ötürü meydana gelen iktisadî problemler ve göç hareketleri verilmeye çalışılmıştır.

Anahtar Kelimeler: Osmanlı Devleti, 17. Yüzyıl, Salgın Hastalıklar, Tâûn/Veba.

${ }^{1}$ Dr.. osmankimya65@mail.com, Orcid: 0000-0003-4168-5224. 
17. Yüzyılda Osmanlı Devleti’nde Meydana Gelen Salgın Hastalıklar...

\title{
The Pandemics that Caused to Social Earthquakes and Migrations in the 17th Century Ottoman Empire
}

\begin{abstract}
Diseases were one of the biggest problems that societies encountered since the beginning of humanity. Those diseases which became pandemics had huge impact on socioeconomic, cultural, military, and political situations throughout history. Pandemics are viewed as one of the most important causes of large-scale deaths. They also caused severe injuries. As the interaction between societies increased, the spreading speed of the pandemics also increased. The Ottoman Empire which ruled over a large territory that was at the junction of important trade routes was specifically affected by this situation. Therefore, the Ottoman State was also influenced from pandemics several times and had to fight against them. By looking at the pandemics occurred in the 17th Century Ottoman Empire, this study analyzes the negative impacts of pandemics on state and society. Furthermore, the economic problems and migration movements caused by the pandemics will be analyzed as well.
\end{abstract}

Keywords: Ottoman State, 17th Century, Pandemics, Plague

\section{GİRIŞ}

İnsanoğlunun yerleşik hayata geçerek tarımsal faaliyetlere başlamasıyla beraber salgın ve bulaşıcı hastalıklar da görülmeye başlanmıştır. Tarımla birlikte hayvancılığın ön plana çıkması bununla birlikte hayvanlarda bulunan ve bulaşıcı olan hastalıklar insanları da etkilemeye başlamıştır. Yerleşik hayata geçiş̧ sürecinde temiz su kaynağı bulma sıkıntısı, farklı toplumlarla kurulan ticarî ve ekonomik etkileşimin artması bir arada yaşamaya başlama sonucunda çeşitli salgınlar ortaya çıkmış ve bu durum toplumları derinden etkilemiştir ${ }^{2}$. Bu salgınlar tarihin çeşitli devirlerinden günümüze kadar insan hayatını büyük oranda tehdit eden unsurların başında gelmiştir. Herhangi bir coğrafyada ortaya çıkan salgın hastalığın boyutuna göre bazen birkaç hafta bazen de birkaç yıl sürerek binlerce insanın ölümüne veya sakat kalmasına neden olmuştur ${ }^{3}$. İlk zamanlarda hastalıkların nedenlerini ve ani ölümleri anlamakta güçlük çeken insanlar, bu durumu çeşitli doğaüstü güçlerle açıklama gayretine girişmişlerdir ${ }^{4}$. Ancak zamanla meydana gelen gelişmeler neticesinde salgınlara karşı insanlar

${ }^{2}$ Kemal Özden, Mustafa Özmat, "Salgın ve Kent: 1347 Veba Salgınının Avrupa'da Sosyal, Politik ve Ekonomik Sonuçları", İdeal Kent Araştırmaları Dergisi, c.12, (2014), 60-87.

${ }^{3}$ Mesut Ayar, Osmanlı Devleti'nde Kolera İstanbul Örneği (1892-1895). İstanbul: Kitabevi Yayınları, 2007. 1.

${ }^{4}$ Orhan Kilıç, Eskiçağdan Yakınçağa Genel Hatlarıyla Dünyada ve Osmanlı Devleti'nde Salgın Hastalıklar. Elazı̆̆g: Fırat Üniversitesi Orta-Doğu Araştırmaları Merkezi Yayınları, 2004. 144.

[2383] 


\section{Osman KİMYA}

çeşitli tedbirler almaya başlamışlardır. Özellikle halk sağlığına önem veren devletler ve milletler ilk çağlardan günümüze salgın hastalıklara karşı geliştirdikleri birtakım önlemlerle korunmaya çalışmışlardır 5 .

İnsanların toplu şekilde ölümüne yol açan ve ortaya çıktığı dönemlerde henüz tedavi şekilleri keşfedilmiş olan bu salgın hastalıklar, tarihin seyrini etkileyen önemli bir faktör olarak karşımıza çıkmaktadır ${ }^{6}$. Meydana gelen salgınlar dünyanın birçok yerinde, devletleri ve toplumları, iktisadî, askerî, sosyal ve siyasî yönden olumsuz etkilemiştir. Salgınlar, kısa bir zamanda hızlı şeklide yayılarak binlerce ve hatta bazen milyonlarca insanın ölümüne yol açmışlardır. Yaşanan salgınlar neticesinde geride zayıflayan ve yıkılan devletler, savaşlar sırasında düşmana karşı değil de salgınlara karşı yenilmiş ordular bırakmıştır. Salgın hastalıklar her devirde toplum üzerinde öylesine derin izler bırakmıştır ki bu izler toplumun kültürüne, yaşamına, sanatına, edebiyatına ve hatta günlük diline dahi yansımışıır?

\section{Osmanlı Devleti'nde Salgınlar}

Pek çok devlet gibi geniş bir coğrafyada uzun yıllar hükmeden Osmanlı Devleti'nde de bazı dönemlerde salgın ve bulaşıcı hastalıklar ortaya çıkmıştır. Osmanlı toplumu da hastalıklardan nasibini almış; veba, cüzzam, çiçek gibi ciddi pek çok hastalık sebebiyle birçok kez ölümlerle yüz yüze gelmiştir ${ }^{8}$. İdareciler bu salgınları önlemek veya toplumsal düzenin sarsılmaması için bir takım tedbirler almaya çalışmışlardır ${ }^{9}$. Ancak alınan çeşitli önlemlere rağmen bu salgınlar ortaya çıktıkları bölgelerde ahaliyi çok zor durumda bırakmıştır. Yaşanan salgınlar neticesinde toplumsal buhranlar yaşanmış ve salgınlar nedeniyle göçler meydana gelmiştir. Salgın hastalıkları önlemek adına çeşitli çalışmalar yapılmıştır. Fakat bu çalışmalar 19. yüzyılın başına kadar da yeterli düzeyde olmamıştır. 19. yüzyılda dünya genelinde sağlık alanında yapılan atılımlarla beraber Osmanlı Devleti'nde de bazı sağlık çalışmaları yapılmaya başlanmıştır.

\footnotetext{
${ }^{5}$ Salgınların tarihsel gelişimi için bkz. Gülten Dinç, "Bulaşıcı ve Salgın Hastalıklar Tarihine Genel Bir Bakış". Yeni Tip Tarihi Araştırmaları Dergisi, c.18, ed. İbrahim Başaoğlu-Gülten Dinç, (İstanbul, 2012), 43-72.

${ }^{6}$ Orhan K1lıç, "Salgın Hastalıkların Osmanlı Vergi Düzenine Etkisi”. Üçüncü İktisat Tarihi Kongresi Bildirileri, c. 1, (İzmir, 25-27 Nisan 2019), 371-384.

7 Gülten Dinç, “Ortaasya Türk Topluluklarından Günümüz Türkiyesine Bulaşıcı ve Salgın Hastalıkların Gelişimi”. Yeni Tip Tarihi Araştırmaları Dergisi, c.18, (İstanbul, 2012), 73-104.

8 Özlem Batğı, "Seyahatnamelerde Osmanlı İnsanının Hastalıkları ve Tedavi Yöntemleri”. Osmanlı Mirası Araştırmaları Dergisi (OMAD), 4/8, (Mart 2017), 169-182.

${ }^{9}$ Gülden Sarıyıldız, Hicaz Karantina Teşkilatı (1865-1914). Ankara: Türk Tarih Kurumu Yayınları, 1996, 5.
} 
Osmanlı Devleti'nde ölümcül salgınları meydana getiren ve toplum hafızasında derin izler bırakan bulaşıcı hastalıklar açısından bakıldığında ilk akla gelen hastalı da genelde veba olmuştur. Osmanlı toplumu bağlamında düşünüldüğünde uzun bir süre öldürücü ve salgın olan hastalıkların hepsinin tâûn veya veba olduğu sanılmıştır. Bir anlamda bu tür hastalıkların hepsine genel olarak veba denilmiştir ${ }^{10}$. Veba Osmanlı kaynaklarında ve halk arasında tâûn olarak da adlandırılmıştır. Tâûn kelime olarak "yaralamak, ayıplamak, kusurlu görmek" manalarındaki ta'n kökünden türemiştir ${ }^{11}$. Veba ise biraz farklı ve geniş mana olarak genel tüm salgın hastalıklar için kullanılmıştır. Osmanlı terminolojisinde bu iki kelime arasında ayrım teorik olarak gözetilse de pratikte genellikle veba ve tâûn eş anlamlı olarak kullanılmıştır ${ }^{12}$.

Evliya Çelebi, Seyahatnâmesinde Osmanlı'da tâûn'un, kıran ve davun gibi isimlerle tanındığından ve genelde salgın hastalıkların adı olduğunu kaydetmiştir ${ }^{13}$. Bu salgın insanlara, fare veya farklı kemirici hayvanlarda mevcut olan pirelerden geçmektedir. Pireler ölen canlıların kanını emerek veba salgınını diğer canlılara ulaştırırlar. Böylece mikroplar bu yollarla insanlara bulaşmaktadır. $\mathrm{Bu}$ şeklide salgın hastalıklar, insan etkileşiminin yoğun olduğu yerlerde daha fazla görülür. Salgın iklim koşullarına bağlı olarak da yayılmaktadır. Yazın sıcak aylarında yayılma durumu daha fazla olan salgınlar soğuk kış şartlarında etkisi azalmaktadır. Veba salgınına yakalanarak ölen insanların yıkanması ve mevcut eşyalarının kullanılması yine salgının yayılmasında önemli bir etken olmaktadır. Vebaya yakalanan insan iki ila altı gün içinde ölmektedir ${ }^{14}$.

Veba ile ilgili tanımlamalar ve araştırmalar ilk dönemlerden itibaren var olmuştur. İbn-i Sina'ya göre; irin bağlayan ve yakıcı sıcaklık veren şişliklerin mevcut olduğu, kulak çevresinde ve kasıklarda meydana gelen illetin adı tâûn

\footnotetext{
${ }^{10}$ K1lıç, "Salgın Hastalıkların Osmanlı Vergi Düzenine Etkisi”. 373; İbn Kayyım el-Cezviyye; “her taun vebadır, fakat her veba taun değildir" ifadesini kullanmıștır. Bkz. İbn Kayyım el-Cezviyyeden aktaran, Nükhet Varlık, "Tâûn”. Türkiye Diyanet Vakfi İslam Ansiklopedisi. İstanbul: TDV Yayınlar1, 2011, c. 40, 175-177.

${ }^{11}$ Bazı dil bilimcilere göre bulaşıp yayılan her hastalık tâûn olarak tanımlanmıştır. Bkz. Nükhet Varlık, “ Tâûn “. 175.

${ }^{12}$ Kılıç, "Salgın Hastalıkların Osmanlı Vergi Düzenine Etkisi”. 374.

${ }^{13}$ Mehmet Yaşar Ertaş-Kağan Eğnim, "Evliya Çelebi Seyahatnamesi’nde Hastalıklar”. Pamukkale Üniversitesi Sosyal Bilimler Enstitüsü Dergisi, c. 10, (2011), 83-107.

${ }^{14}$ Adem Çalışkan-Ahmet Eyicil, "XVIII. ve XIX. Yüzyılda Halep ve Civarında Salgın Hastalıklar". Bingöl Üniversitesi Sosyal Bilimler Enstitüsü Dergisi, c. 9, sy. 18, (2019), 1289-1319.
} 


\section{Osman KİMYA}

yani vebadır ${ }^{15}$. Naima ise eserinde kısa zaman içerisinde ölümcül olan hastalıklar için "hummâ-yı vebâ'iyye" tanımını yapmıştır".

\section{17. Yüzyılda Meydana Gelen Salgınlar}

Osmanlı toprakları bulunduğu konum itibariyle yüzyıllar boyunca pek çok veba salgınına maruz kalmıştır. İstanbul, İzmir, Selanik, Halep, İskenderiye ve Kahire gibi Osmanlı vilâyetleri bu salgınlardan en çok yara alan yerler arasında yer almışlardır ${ }^{17}$. Osmanlı Devleti'nde 17. yüzyıldaki ilk salgın hastalığın tespit edilebildiği kadarıyla 1610 yılında vuku bulduğu anlaşılmaktadır. 9 Cemâziye'levvel 1019/30 Temmuz 1610'da Larende kadısına yazılan hükümde Veziriazam Davud Paşa haslarına tabi olan köylerde tâûn'un zuhur ettiği görülmektedir. Köylerdeki ahalinin birçoğunun meydana gelen tâûn illetinden öldüğü bildirilmiştir. Bu salgın neticesinden ölümler ve göçler nedeniyle Davud Paşa haslarından olan köylerin çoğunun boşalmaya başladığı yazılmaktadır. $\mathrm{Bu}$ durumda voyvodalar boş kalan köyleri zaptederek kendilerine tabi hale getirmişlerdir ${ }^{18}$.

10 Zi'l-hicce 1025/19 Aralık 1619'da Livadye'de bir tâûn salgının vuku bulduğu görülmektedir. Hükümlerde geçen ibarelerden yörede Voyvoda olarak bulunan Mehmet Ağa'nın geçmiş yıllara ait olan vergilerin eksik tahsil edilmesinin nedenlerini açıklarken; vilâyete zuhur eden tâûn salgını neticesinde re’âyânın "on ekserinin" (onda birinden fazlası) ölmüş olması ve ayrıca kendisinden önceki zaman diliminde görevli olan voyvodanın vilâyette mevcut vergileri tahsil ederken kanunlarda belirlenen resmi rayice göre değil, mahâlli rayic üzerinden vergileri toplamış olmasıdır ${ }^{19}$. Anlaşıldığı kadarıyla Livadye'de tâûn salgını 17. yüzyılda birkaç kez vuku bulmuştur. Nitekim Livadye'yi 1667 yılında ziyaret eden Evliya Çelebi, Livadye'nin hâne sayısını toplamda 2.000 olarak kaydetmektedir. İncelemeler neticesinde Livadye nüfus'un \% $10^{\text {‘undan }}$ fazlasının zuhur eden tâûn dolayısıyla öldüğü anlaşılmaktadır ${ }^{20}$.

\footnotetext{
15 Sevda Ağır, Osmanlı'da Karantina Uygulama Süreçleri ve Tepkiler (1865-1914). Ankara: Hacettepe Üniversitesi Sosyal Bilimler Enstitüsü, Yüksek Lisans Tezi, 2020, 12.

16 Naîmâ Mustafa Efendi, Târih-i Na'îmâ. Haz. Mehmet İpşirli. Ankara: Türk Tarih Kurumu Yayınları, 2007, c. 4, 1693.

17 Panzac'ın Osmanlı şehirlerinde salgınlarla alakalı yaptığı çalışmalarında Halep'te 1669, 1685, 1686 ve 1690-1691'de taun/veba salgınlarının meydana geldiğini ve ahalinin birçoğunun bu salgınlardan öldüğünü vurgulamaktadır. Bkz. Daniel Panzac, Osmanlı Imparatorluğu'nda Veba (1700-1850). Türkçe çev. Serap Yılmaz, İstanbul: Tarih Vakfi Yurt Yayınları, 1997, 5.

${ }^{18}$ Başbakanlık Osmanlı Arşivi, BOA, A.DVN.MHM.d,79/768, 1019 Ca. 9/30 Temmuz 1610.

${ }^{19}$ Topkapı Sarası Müzesi Arşivi, TSMA., d. 1306/63, 1025 Z. 10/19 Aralık 1619.

20 Evliya Çelebi Livadye'nin 14 mahalleden meydana geldiğini, bunlardan 8 mahallenin
} 
17. Yüzyılda Osmanlı Devleti’nde Meydana Gelen Salgın Hastalıklar...

10 Zi'l-hicce 1025/19 Aralık 1619'da Halep Kadısı Mehmed Şerif tarafindan merkeze yazılan arizada Tunus, Cezayir, İskenderun ve Halep taraflarından bir seneden beri devam eden tâûn salgınının olduğu belirtilmiştir. Arizanın devamında yaşanan tâûndan ötürü bir yıldan fazladır İskenderun İskelesi'ne hiçbir geminin gelmediğini ve her yıl gelen gemilerden vergi tahsil edildiğini ancak bu yıl hiç bir verginin alınamayacağı vurgulamaları bu bölgede büyük bir tâûn salgınının olduğunu göstermektedir ${ }^{21}$. Aynı bölgede 20 Cemâziye'l-âhir 1037/19 Mart 1626'da yazılan bir hüccette yeni bir tâûn salgınının meydana geldiği anlaşılmaktadır. İskenderun voyvodaları Ramazan ve Mustafa Ağalar, bir seneden beri tâûndan ötürü İskenderun İskelesi'ne hiçbir geminin yanaşmadığını bildirmişlerdir. Bu durumdan hem mirî hazinenin ve hem de kendilerinin etkilendiğini vurgulamışlardır ${ }^{22}$.

8 Rabîu'l-âhir 1027/4 Nisan 1618 tarihinde yine Bursa'da tâûn hastalığının zuhur ettiği dönemin yazışmalarına yansımaktadır. Bursa'da Emir Buhari evkafından Kite Kazası'na bağlı İşkil-i Kebir Köyü'nün cizye vergisine tabi yüz altmış Hristiyan ahalisinden yetmiş üçünün tâûn salgınından öldüğü anlaşılmaktadır. Bursa kadıları tarafından merkeze yazılan hüccetlerde tâûndan ölenlerin cizye defterlerinden düşürülmesi için talepte bulunulmuştur ${ }^{23}$. 1042/1632-1633 senesinde Rumeli'de tâûnun meydana geldiği Evliya Çelebi'den öğrenilmektedir. Meydana gelen taun salgınına Rumeli Kazaskeri Kara Çelebizade Mehmed Efendi'de yakalanarak vefat etmiştir ${ }^{24}$. 14 Şevval 1053/26 Aralık 1643'te Arhos'da bir tâûn salgını vuku bulmuştur. Bu durum Arhos'un cizye vergilerinde yapılan tahkikatla anlaşılmıştır. Vazifeli olan Faik Paşa tarafindan yapılan tahrir işleminde yörede tâûnun zuhur ettiğini ve bu salgından ötürü halkının çoğunun öldüğü belirtilmiştir. Vilayetin cizye hanelerinin doğru tespiti için yeniden tahrir işlemi yapılmıştır ${ }^{25}$.

1648-1649 İngiliz tüccar olan ve ticaret maksadiyla pek çok kez İstanbul'a gelen Bargrave İstanbul ile akalalı olarak kaydettiği notlarında bir veba salgınından bahsetmektedir. Yaşanan bu veba salgını hakkında; sokakların

\footnotetext{
Müslümanlara ait olduğunu, 6'sının ise kefere mahallesi olduğunu kaydetmektedir. Ayrıca Livadye'nin toplam hâne sayısının ise iki bin olduğunu kaydetmektedir. Bkz. Evliya Çelebi, Seyahatnâme. Haz. Seyit Ali Kahraman-Yücel Dağlı, İstanbul: Yapı Kredi Yayınları, 2006, c. 5, 460-462. Hâne olarak 2000x5=10.000 nüfusa sahip olmas1 muhtemeldir

${ }^{21}$ BOA, TSMA, d, 1341/2, 1025 Z. 10/ 19 Aralık 1619.

${ }^{22}$ BOA, TSMA, d, 1341/1, 1037 C. 20/19 Mart 1626.

${ }^{23}$ BOA, TSMA. e, 6841/4-9, 1027 R. 8/4 Nisan 1618.

${ }^{24}$ Bkz. Evliya Çelebi, Seyahatnâme. 1/220.

${ }^{25}$ BOA, MAD.,d, 15948, 1053 L. 14/26 Aralık 1643.
} 


\section{Osman KİMYA}

cesetlerin kokusundan geçilmediğini belirtmektedir ${ }^{26}$. Bargrave'nin bu ifadeleri biraz abartı içerebilir, ancak bu notlardan anlaşıldığı kadarıyla İstanbul'da bir veba salgını yaşanması ve bu salgının ticaret için gelen tüccarların tuttuğu notlara konu olmasi muhtemeldir.

23 Cemâziye'l-evvel 1058/15 Haziran 1648'de Erzurum Eyaleti'nde başlayan bir salgının olduğu yine yazışmalardan anlaşılmaktadır. Erzurum'daki idareciler tarafından merkeze yazılan arzlardan eyalette büyük bir tâûnun vuku bulduğunu, bundan ötürü vefat edenlerin sayısının fazla olduğu üzerinde durulmaktadır. En kısa zamanda vergi mükelleflerinin yeniden tespit edilmesi amacıyla yeni tahririn yapılması ve vefat edenlerin defterden ihraç ve tenzil edilmesi istenmiştir ${ }^{27}$. Aynı Eskihisar ${ }^{28} \mathrm{Kad}_{1} \mathrm{~s}$ tarafından gönderilen bir hüccette yörede yine tâûn salgının zuhur ettiği anlaşılmaktadır. Hüccette halkın çoğunun salgından muzdarip olduğunu ve ödemesi gereken sürsat zahiresinden kısmen bir indirim yapılması talep edilmiştir ${ }^{29}$.

18 Şaban 1058/7 Eylül 1648'de bir başka tâûn salgını Kesindire'de ortaya çıkmıştır. Yerel yöneticiler yaşanan salgından dolayı halkın çok zor durumda olduğu ve vakfa ödenmesi gereken vergilerini dahi ödeyemediklerini merkeze iletmişlerdir. Sultan İbrahim tarafından yazılan ferman gereği Kesendire sakinleri 1648 senesi vergilerden muaf tutulmuşlardır ${ }^{30} .4$ Recep 1062/11 Haziran 1652'de Haremeyn Evkafı'ndan Erikli ve Tevabii köylerinin zuhur eden büyük tâûndan dolayı perişan olması vergilerin ödenememesi ile neticelenmiştir. Yöneticiler salgının o kadar çok kişiyi etkilediği üzerinde durmuşlardır ki hem menzil hem

${ }^{26}$ Robert Bargrave, The Travel Diary of Robert Bargrave (Levant Mercant 1647-1656). Haz. Michael G.Brennan, London: The Hakluyt Society, 1999, 60-73.

${ }^{27}$ BOA, MAD.d, 15633, 1058 Câ. 23/15 Haziran 1648.

${ }^{28}$ Eskihisar; bu dönemde Anadolu Eyaleti'ne bağlı bir kaza konumundadır. Bkz. Tahir Sezen, Osmanlı Yer Adları. T.C. Başbakanlık Devlet Arşivleri Genel Müdürlüğü Yayını, 2017, 258.

${ }^{29}$ BOA, TSMA, e, 522/15, 1058 Câ. 23/15 Haziran 1648; Sürsat; Ordu sefere giderken yol üzerindeki köylerin ahalisi ordunun takip edeceği yol güzergâhlarına zahire getirmesi ve karşıllı̆ı verilecek şekilde bedeli üzerinden satmakla vazifeli olmaktaydı. Ancak sonradan bu mükellefiyete bedel kendilerinden küçük oranda bir vergi alınmakla iktifa olundu. Bu şekilde sattıkları ürünlere sürsat zahiresi ve verdikleri vergiye ise sürsat bedeliyesi denilmekteydi. Bkz. Midhat Sertoğlu, Osmanl Tarih Lugatı, Kurtuba Kitapları, İstanbul, 2015, s.497.; Mehmet Zeki Pakalın, Osmanl Tarih Deyimleri ve Terimleri Sözlüğü. İstanbul: Milli Eğitim Bakanlığı Yayınları, 1993, c. 3, 300; Sürsat mükellefiyeti un ve arpadan dışında, odun, ekmek, saman, yağ, koyun, bal ve bazen de ot gibi ürünleri gibi ihtiva etmekteydi. Bu ürünleri vermekle mükellef olan ahali, belli maddeleri görevlilerin belirlediği rayiç bedelinden daha az satma zorunluluğu getirildi. Sürsat vergisi veya zahiresi, XVII. yüzyılın başlarından itibaren hem bedelen hem aynen tahsil edilmeye başlandı. Bkz. Ömer İşbilir, "Nüzül”. Türkiye Diyanet Vakfi İslam Ansiklopedisi, İstanbul: TDV Yayınları, 2007, c. $33,311-312$.

${ }^{30}$ BOA, TSMA. e, 798/49, 1058. Ş. 18/7 Eylül 1648. 
17. Yüzyılda Osmanlı Devleti’nde Meydana Gelen Salgın Hastalıklar...

de hane-i avarıza tahammülleri kalmamıştır. Haremeyn vakıflarının yöneticisi olan Darüssaade Ağası Süleyman Ağa hükümete halkın hane-i avarızlarının ref' edilmesini arz etmiştir ${ }^{31}$.

$\mathrm{Bu}$ yüzyılda Osmanlı Devleti egemenliğindeki toprakların birçoğunda salgıların meydana geldiği görülmektedir. Yaşanan en önemli salgın felaketi ise tâûn/veba olmuştur. Rumeli'yi ziyaret eden Evliya Çelebi, Rumeli'de meydana gelen önemli bir veba'dan bahsetmektedir. Yenişehir'i ziyareti sırasında Yenişehir Mollası olan Hasımzâde Abdulbaki Efendi'nin 17. yüzyılın ortalarında yaşanan bir veba salgınında yöre ahalisinin 20.000'den fazlasının tâûndan vefat ettiğini kendisine naklettiğini kaydetmektedir ${ }^{32}$. Aynı şekilde 1652'de Sofya'da bulunan Evliya Çelebi, burada çok etkili bir tâûn salgınını haber vermektedir. Malum salgının kısa sürede kentte yayıldığını ve günde yaklaşık 500 insanın bu salgından vefat ettiğini yazmaktadır. Salgından 67 tane devlet görevlisi de vefat etmiştir. Hatta Melek Ahmed Paşa dahi bu salgına yakalanmaktan kendini kurtaramamıştır ${ }^{33}$.

11 Cemâziye'l-âhir 1065/18 Nisan 1655'de Erzurum Eyaleti ve çevresinde yeni bir tâûnun zuhur ettiği görülmektedir. Erzurum'a bağlı köy ve kasabaların avarız haneleri meydana gelen tâûn hastalığından kısmen vefat ve kısmen de köylerin harap olduğu her zamanki gibi yerel yöneticiler tarafından merkeze arz edilmiştir. Bunun üzerine Erzurum'da görevli Cafer Ağa marifetiyle bölgede yeniden tahrir yapılması ve noksan olan hanelerin vergiden düşülmesi talep edilmiştir ${ }^{34}$.

${ }^{31}$ BOA, İE, SH, 2/134, 1062 B. 4/11 Haziran 1652.

32 Bkz. Orhan Kılıç, "16-18. Yüzyıllarda Balkan Şehirlerinde Yaşanan Veba Salgınları ve SosyoEkonomik Etkileri”. Osmanlı Dönemi Balkan Şehirleri, ed. Zafer Gölen-Abidin Temizer, Ankara: Gece Kitaplığı Yayınları, 2016, c. 3, 1188.

33 “Tanrı'nın hikmeti günden güne veba şehir içinde yayılmaya başladı. Bir ay sürdü ve her gün beşer yüz insan ölürdü. Ta bu derece ilerledi ki nice bin adam Sofya'dan kaçıp diğer beldelere gittiler. Hatta devlet sahibi efendimizin 67 ünlü ve namlı iskemle sahibi ă̆aları öldü. Paşa da ağrı hastalığı deyip yatağa düstü. Hatta başı Adana kabă̆ı kadar olup dili kapkara yandı, kulaklarından cerahat akıp bir kaç kere can çekişir hale geldi.” Bkz. Evliya Çelebi, Seyahatnâme, c. 3, 531; Melek Ahmed Paşa, Sultan I. Ahmed döneminde çocuk yaşta saraya alınmıştır. Enderunda eğitim görmüş. 1639'da vezirlik rütbesi ile Diyarbakır eyaleti valisi olmuştur. Daha sonra Bağdat valisi ve Şam valiliği yapmıştır. 1644'te İstanbul'a tayin edilip aynı yıl Sultan IV. Murad'ın kızı İsmihan Kaya Sultan ile evlenerek saraya damat olmuştur. 5 Ağustos 1650'de sadrazam olmuştur. 1651'de azledilmiş ve İstanbul'dan uzaklaştırılmıştır. Daha sonra yeniden İstanbul'a dönen paşa çeşitli vazifeler yapmıştır. 1662'de İstanbul'da vefat etmiştir. Evliya Çelebi ile yakın dostluğa sahiptir. Bkz. Fikret Sarıcaoğlu, "Melek Ahmed Paşa". Türkiye Diyanet Vakfi İslam Ansiklopedisi, Ankara: TDV Yayınları, 2004, c. 29, 42-44.

${ }^{34}$ BOA, MAD.d, 14739, 1065 C. 11/18 Nisan 1655. 


\section{Osman KİMYA}

07 Cemâziye'l-evvel 1070/18 Ocak 1660'ta Kefe'de vazifeli Mehmed Efendi tarafından tutulan deftere göre Selanik ve Üsküp'te tâûn hastalığının vuku bulduğu kaydedilmiştir. Kayıtlara göre bu hastalıktan toplamda 57 hanenin vefat ve diğer yollarla eksildiği anlaşılmaktadır. Üsküp kadısı tarafindan merkeze arz tezkeresi yazılmıştır. Verilen cevapta Selanik ve Üsküp'te hastalıktan etkilenenlerin isimlerini, bunların avarız-1 tekâlifiyyeden muaf olmaları ve yalnızca sürsat bedeline dâhil olmaları istenmiştir ${ }^{35}$. Aynı sene Göynük ve köylerinde bir salgın vuku bulmuştur. Bu salgında Göynük ahalisinin bir kısmı tâûndan vefat etmiştir. Özellikle Göynük'e tabi olan Boyalıca Köyü meydana gelen tâûndan çoğu vefat etmiş, geriye kalan ahalide bulaşıcı hastalık korkusuyla başka topraklara göç edince köyde sadece üç kişinin kaldığı yazışmalarda geçmektedir. Bu durum yine vergi meselesinde gündeme gelmiş, vefat eden ve göç yolunu tutan ahali vergiden düşülmüştür ${ }^{36}$.

17 Rabîu'l-âhir 1071/20 Aralık 1660’da Eğriboz Adası'nda ortaya çıkan tâûn hastalığı yaklaşık üç yıl sürmüştür. Burada ikamet etmekte olan gayrimüslim ahalinin çoğu hastalıktan perişan olup ölmüştür. Yazılan talimatlarda Eğriboz Ceziresinde ahalinin hane sayısının yeniden belirlenerek kendilerinden ağır cizye talebinde bulunulmaması istenmiştir ${ }^{37}$. Evliya Çelebi 1668'de yaptığı seyahatinde Karlıili Sancağı'na tabi Zeban kasabasına uğramış, kasabanın dört senedir devam eden tâûn sebebiyle nüfusunun çok az olduğunu ve salgının halen devam ettiğini kaydetmiştir ${ }^{38}$.

6 Rabîu'l-âhir 1091/4 Temmuz 1680'de Biga Sancağı ve Çan Kazası'nda zuhur eden vebadan ahalinin çoğu vefat etmişti. Salgından hayatta kalanlar ise üzerlerine tarh edilen her zamanki vergiyi ödeyemeyeceklerinden göç ederek başka yerlere gitmeye başlamışlardır. Durumun vehameti Biga Kadısı'nın, yeniden nüfus tahriri yapılıp vergi düzenlenmesi yapılması için merkeze yazdığ arzdan anlaşılmaktadır. Bu durum söz konusu salgın hastalıklardan ötürü meydana gelen buhranı göstermesi açısından önemlidir ${ }^{39}$. Aynı y1l Hatvan Kalesi'nde tâûn hastalığı görülmüş ve kaledeki muhafizların ekserisi tâûn illetinden vefat etmişlerdir. Kadı Salih ve Mirliva Dilaver tarafından merkeze durumla alakalı arz gönderilmiştir. Arzda Hatvan Kalesi'ne yeni takviye muhafızların gelmesi gerektiği üzerinde önemle durulmuştur. Zira Hatvan

\footnotetext{
35 BOA, MAD.d, 14680, 1070 Câ.7/18 Ocak 1660.

${ }^{36}$ BOA, C. SH, 25/1204, 1070 Câ.7/18 Ocak 1660.

${ }^{37}$ BOA, AE, SMMD. IV, 83/9828, 1071 Râ. 17/20 Aralık 1660..

38 Bkz. Kılıç, "16-18. Yüzyıllarda Balkan Şehirlerinde Yaşanan Veba Salgınları ve SosyoEkonomik Etkileri”. c. 3, 1191.

${ }^{39}$ BOA, İE, DH, 3/262, 1091 Râ. 6/4 Temmuz 1680.
} 
Avusturya sınırında önemli bir kaledir ${ }^{40}$. Çok değil iki yıl sonra bu defa tâûn Anadolu'da (13 Recep 1093/6 Temmuz 1682) Kastamonu nahiyelerinden Kürei Nühas Nahiyesi'nde kendini göstermiştir. Bu salgın hastalık nahiyede maden ihracında çalışan köle ve esirlerin tâûn sebebiyle telef oldukları Küre-i Nühas Kadısı Mustafa tarafından durum Kastamonu Sancak Beyi'ne bildirilmiştir ${ }^{41}$.

Son derece hızlı bir şekilde yayılan ve binlerce insanın ölmesine neden olan tâûn Özellikle 17. yüzyılın son dönemlerinde Batı Avrupa'da azalsa da, Osmanlı Devleti'nde tam tersi bir durum söz konusu olmuştur. Bunun muhtemel nedeni Osmanlı Devleti'nin ticaret yollarının güzergâhında bulunan bir konumda olmasıdır. Dolayısıyla Osmanlı topraklarında tâûn hastalı̆̆ 1 görülmeye devam etmiştir ${ }^{42} .10$ Safer 1103 'te yine Bağdat taraflarında bulunan Kavarna Kalesinde tâûn hastalığı zuhur etmiş̧tir. Bağdat Valisi Ahmed Paşa, Kapıkulu Ağası Haseki Osman Ağa'ya askerlerinin büyük çoğunluğunun hastalıktan vefat ettiğini bildirmiştir.Ayrıca Bağdat Kalesi muhafazasında olan bir kısım yeniçerilerin Karvarna Kalesine gönderilmesini talep etmiştir.

Bolu Sancağı'nın Zerzen Kazası'nın Gönliye Köyünün sakinleri yine çoğunluğu tâûn hastalığından vefat etmiştir. 18 Şevval 1106/1 Haziran 1695'de Bolu sancağı idarecileri tarafından durum merkeze bildirilmiştir. Gelen cevapta ise yaşanan salgın ve vefatler nedeniyle karyenin kalan ahalisinin tekâlifi mirîyeden muaf olmaları istenmiştir. ${ }^{43}$ Aynı tarihte Hotaliç ${ }^{44}$ Kazası'nda tâûnun vuku bulduğunu ve bu hastalık nedeniyle ahalinin vefat ettiğine dair nâib İbrahim tarafindan arzlar yazılmışııı ${ }^{45}$.

17. yüzyılın sonlarında meydana gelen salgın hastalık yaklaşık üç sene sürmüş ve Osmanlı Devleti'nin her tarafindan bu hastalıkla ilgili yaşanan problemler yazışmalara yansımıştır. 1 Ramazan 1108/24 Mart 1697'de Prevadi Kazası'na tabi Hascık Köyü ahalisinin ekserisi tâûndan vefat ettiği yine yazışmalardan anlaşılmaktadır. Görevliler tarafından yazılan arzlarda tekaliflerden ahalinin muaf tutulması talep edilmektedir ${ }^{46}$. 13 Şevval 1108/5 Mayıs 1697'de Alaiye, Aydın, Menteşe ve Saruhan bölgelerinde bulunan görevliler tarafindan tâûn hastalığının zuhur eylediğine ve teferruatına dair

\footnotetext{
${ }^{40}$ BOA, İE, SH, 1/53, 1091 Râ. 6/4 Temmuz 1680.

41 BOA, A.DVN.MHM.d, 102/271, 1093 B. 13/6 Temmuz 1682. Küre-i Nühas bu dönemde Kastamonu Eyaletine bağlı İneboluya tabi bir nahiyedir. Bkz. Sezen, Osmanlıda Yer Adları, 503.

${ }^{42}$ Panzac, Osmanlı Imparatorluğu'nda Veba (1700-1850), 1.

${ }^{43}$ BOA, İE, DH, 15/1381-1385, 1106 L. 18/1 Haziran 1695.

${ }^{44}$ Hotaliç; XVII. Yüzyılda Rumeli Eyaletine tabi bir kazadır. Sezen, Osmanlı Yer Adları, 356.

${ }^{45}$ BOA, İE, SH, 2/120, 1106 L. 18/1 Haziran 1695.

${ }^{46}$ BOA, İE, SH, 1/100, 1108 L. 1/ 24 Mart 1697.
} 
arzların merkeze yazıldığı görülmektedir ${ }^{47}$. Keşan Kazası'nda yaşanan salgından dolayı Arnavudlar Köyü halkı perişan duruma düşmüşlerdir. Felaketlerden sonra yaşanan durum gereği vermeleri gereken vergilerin tenzil edilmesine dair taleplerini önce kaza naibi Ali Efendi'ye başvurmuşlardır. Naib Ali Efendi halkın bu isteklerini ve perişan durumlarını merkeze arz etmiştir ${ }^{48}$. Aynı yıl salgın Viranşehir Kazası'na tabi köylerde de görülmektedir. Bu defa durumu bildiren görevli doğal olarak Viranşehir naibi Nâib Mehmed Efendi'dir. Keşan naibi gibi Viranşehir naibi de merkeze gönderdiği arzında tâûn salgınlarından ötürü ahalinin zor durumda olduğunu ve hâne-i avârızın tenzil edilmesini talep etmiştir $^{49}$. Yine 12 Ramazan 1109/14 Mart 1698'de Yanbolu ve havalisinde tâûn salgının zuhur ettiği görülmektedir. Yanbolu Kadısı Osman tarafından bu hastalık ile alakalı olarak merkeze bilgi verilmiş ahalinin bu seneki tekaliflerden muaf tutulması talep edilmiştir ${ }^{50}$.

20 Zi'l-kâde 1109/30 Mayıs 1698'de Hasköy Kazası'na tabi bazı köylerde tâûnun zuhur ettiği ve bu salgından birçok köy ahalisinin vefat ettiği Kadı Abdulhalim tarafindan merkeze yazılan arizadan anlaşılmaktadır ${ }^{51}$. Aynı tarihte Viranşehir'de de Kadı Şaban tarafindan yazılan arzda Viranşehir'e tabi köylerde tâûn salgınının halen devam ettiğini ve halkı etkilediği kaydedilmektedir ${ }^{52} .29$ Safer 1110/6 Eylül 1698'de Bolu Sancă̆ı'nda salgın hastalık görülmektedir. Kadı Abdullah tarafından merkeze yazılan arzda Bolu Sancağı'na tabi Germedes Köyü ahalisinin iki erkek dışında tamamının tâûndan vefat ettiği anlaşılmaktadır ${ }^{53}$. 6 Rabîu'l-evvel 1110/12 Eylül 1698'de tâûn salgının Hamid Sancağı ve Arabgir Kazası'nda da olduğu yine yazışmalarda karşımıza çıkmaktadır. Hamid Sancağı kadısı Abdullah ve Arabgir Kazası kadısı Mustafa tarafindan yazılan arzlarda tâûn hastalı̆̆ının meydana geldiği ve ahalinin çoğunun vefat ettiği yazılmaktadır. Hastalık korkusuyla bir kısım ahalinin ise göç ettiği anlaşılmaktadır ${ }^{54}$. Aynı günlerde Konya havalisinde meydana gelen kıtlık ve tâûndan ahalinin çoğunun öldüğü ve sağ kalanların ise göç ettiği hükümlerden anlaşılmakadır. Geriye kalan ahali ise hâne-i avârızlarını ödeyemeyecekleri anlaşılınca görevliler tarafından merkeze yazılan arzlarda muaf tutulmaları taleb edilmiştii $^{55}$. Manastırdan yazılan arzlarda yine durumun aynı olduğu ve ahalinin

\footnotetext{
${ }^{47}$ BOA, İE, SH, 2/122, 1108 L. 13/5 May1s 1697.

${ }^{48}$ BOA, İE, SH, 2/136. 1108/1696-1697.

${ }^{49}$ BOA, İE, SH, 2/124. 1108/1696-1697.

${ }^{50}$ BOA, İE, SH, 2/125, 1109 L. 12/14 Mart 1698.

${ }^{51}$ BOA, İE, DH, 18/1723, 1109 Zâ. 20/30 Mayıs 1698.

${ }^{52}$ BOA, İE, SH, 2/137, 1109 Zâ. 20/30 Mayıs 1698.

${ }^{53}$ BOA, İE, DH, 12/1177, 1110 S. 29/6 Eylül 1698.

${ }^{54}$ BOA, İE, SH, 2/127, 1110 Râ. 6/12 Eylül 1698.

${ }^{55}$ BOA, İE, DH, 16/1521.
} 
malum hastalıktan çoğunun vefat ettiği yazılmaktadır. Geriye kalan ahali perişan halde olduğundan tekaliflerden yine muafiyetleri istenmiştir ${ }^{56}$.

Osmanlı Devleti'nde özellikle yüzyılın son senelerinde bir çok bölgede salgınların olduğu anlaşılmaktadır. 1699 senesinde Karadağ' da bir tâûn salgının olduğu yine yazışmalardan anlaşılmaktadır ${ }^{57}$. Bulgaristan'da bulunan Razlık Kasabası'nda yine aynı tarihlerde bir veba salgını zuhur etmiştir. Veba dolayısıyla ahalinin büyük çoğunluğu vefat etmiştir. Kadı Mehmed Şeyhi Efendi tarafından avarız ödemelerinin tenzil edilmesi içn merkeze arzlar yazılmıştır ${ }^{58}$.

Bu yüzyılda yaşanan salgınlarla ilgili olarak Fransız seyyah Thevenot'ın seyahatnâmesindeki notlarına bakıldığında tâûn salgını yedi yılda bir Mısır'da meydana geldiğini, sadece Mısırda değil tüm Türk topraklarında her yıl binlerce can aldığını kaydetmektedir ${ }^{59}$. Parisli seyyah ve tüccar Tavernier ise Osmanlı topraklarındayken ticaret maksadıyla İzmir'de bir süre kalır. Aldığı notlarında salgın hastalıktan bahseder ve İzmir'de hemen hemen her y1l salginların görüldüğ̈̈nü kaydetmektedir. Yine görülen salgınların genelde yaz aylarında görüldüğ̈̈nü, ancak meydana gelen salgınları batıdaki salgınlar kadar büyük çaplı olmadığını vurgulamaktadır ${ }^{60}$.

\section{Yaşanan Salgınların Toplum Üzerindeki Etkileri}

Salgın hastalıklar tarih boyunca pekçok devlet üzerinde önemli etkiler bırakmıştır. Kuşkusuz bu tarz salgın hastalıklara Osmanlı Devleti'de konumu gereği birçok kez maruz kalmıştır. Osmanlı topraklarında meydana gelen salgın

\footnotetext{
${ }^{56}$ BOA, İE, SH, 2/105.

${ }^{57}$ BOA, İE, SH, 2/127, 1110 Râ. 6/12 Eylül 1698.

${ }^{58}$ BOA, İE, SH, $2 / 159$.

59 Jean Thevenot (1633-1667) Fransız doğu gezginidir. 18 yaşından itibaren Avrupa'yı gezmeye başlamıştır. Dünyanın pek çok yerini dolaşan Thevenot'un bilinen tek mesleği gezginliktir. Genç yaşta ölmesine rağmen yazdığ 1 Thevenot Seyahatnamesi Osmanlı Devleti için önemli bir kaynak niteliği taşımaktadır. Bkz. Jean Thevenot, Jean Thevenot Seyahatnamesi. Tükçe çev. Ali Berktay, İstanbul: Kitap Yayınevi, 2014, 250.

${ }^{60}$ Jean Baptiste Tavernier, 17. Yüzyılda Topkapı Sarayı. Türkçe çev. Teoman Tunçdoğan, (İstanbul: Kitap Yayınları, 2007), 117-118. Parisli bir seyyah olan Tavernier1605'te Paris'te dünyaya gelmiştir. Babası ve amcasının haritacı olması üzerine, onların etkisinde kalan Tavernier seyyah olmaya karar vermiştir. 16 yaşında başladığı seyahatlerini hayatı boyunca devam ettirmiştir. Zaten 1689 'da ülkesinden çok uzakta Moskova'da ölmüștür. Hindistan-Fransa ticaretinin öncülerindendir. 1631'de İstanbul'a gelen seyyah buradaki bir yıllık izlenimlerini 17. Yüzyılda Topkapı Sarayı adıyla Paris’te yayınlamıştır. Bunun dışında seyahat ettiği ülkelerle ilgili pek çok eser kaleme almış önemli bir Fransız seyyahıdır. Bkz. Zeki Arıkan, "Jean Baptiste Tavernier". Türkiye Diyanet Vakfi İslam Ansiklopedisi, Ankara: TDV Yayınları, 2011, c. 40, 181-183.
} 
hastalıkların toplum üzerinde önemli iktisadî, siyasî ve coğrafî etkilerinin görülmesi kaçınılmaz olmuştur. Her yüzyılda olduğu gibi bu yüzyılda da salgınlar birçok bölgede muhtelif tarihlerde zuhur etmiş ve devleti zor durumda bırakmıştır. Özellikle askeri kuvvetler, hacılar ve sürekli hareket halinde olan tüccarlar aracılığıyla bulaşıcı hastalıklar Osmanlı toplumuna sirayet etmiştir. Bununla birlikte devlet içerisinde vuku bulan siyasî ve iktisadî buhranlar, kaybedilen savaşlar sonrasında meydana gelen göçler ve fakirlik gibi unsurlar hastalıkların yayılma hızının artmasına sebep olmuştur. Devlette bu yüzyılda da sık sık salgın hastalıkların yaşanması hadisesi aynı zamanda pek çok probleme sebep teşkil etmiştir. 17. yüzyıla bakıldığında göze çarpan önemli bir problem salgınlardan sonra salgın bölgesinde binlerce insanın ölmesi o yörede vergi sorunlarını meydana getirmiştir. Bir diğer önemli sorun salgınların zuhur etmesiyle insanlar salgından etkilenmemek adına göç yolunu tutmalarıdır.

\subsection{Salgınlar Nedeniyle Yaşanan Vergi Problemleri}

Salgın hastalık vuku bulduğu coğrafyada toplumu birçok noktada olumsuz etkilemiştir. Toplumda meydana getirdiği en önemli sorunlardan biri vergi olmuştur. Tüm devletlerde olduğu gibi Osmanlı Devleti'ni de tüm müesseseleriyle ayakta tutan önemli etken ahaliden toplanan vergilerdir. Osmanlı iktisadî düzeninde her fert aynı zamanda bir vergi mükellefiydi. Tabi bu vergi mükellefiyetinde birtakım muaf zümrelerde bulunmaktaydı. Toplanan vergi gelirlerinin birçoğu merkezî hazineye aktarılmaktaydı. Devlet giderlerinin tamamı genel mahiyette merkezî hazineden karşılanmaktaydı. Dolayısıyla meydana gelen salgın hastalıklar devletin vergi gelirlerini önemli ölçüde etkilemekteydi. Vergi hasılatı yetersiz olduğunda vergiye dayalı işlerde ve ödemelerde haliyle aksaklıklar görülmekteydi. Salgılardan sonra meydana gelen toplu ölümler nedeniyle yöre halkı mükellef olduğu vergileri ya eksik ödemekte veyahut hiç ödeyememekteydi. Bir bölgede bu şekilde toplu ölümler olunca dirlik sahipleri alması gereken ödemeleri alamamaktaydı. Bu gelirler tahsil edilmeyince merkezî hazineye gitmesi gereken tahsilat azalmaktaydı. Meydana gelen bu tarz krizler devlette ekonomik problemlerin yaşanmasına ve beraberinde askerî, siyasî ve sosyal sorunlara neden olmaktayd ${ }^{61}$.

Osmanlı Devleti salgınların meydana geldiği bölgelerdeki işleyişin aksamaması yada ahalisinin göç etmemesi adına belli zaman diliminde o yöreye vergi muafiyeti sağlamaktaydı. 17. yüyıldaki kayıtlar incelendiğinde bu tarz pekçok hüküm örneği karşımıza çıkmaktadır. Bu yüzyılda meydana gelen salgın

${ }^{61}$ Bkz. Kılıç, “Salgın Hastalıkların Osmanlı Vergi Düzenine Etkisi”. c. 1, 374.

[2394] 
hadiselerinde yöre idarecileri merkezî idareye yazdığı arzlarda çeşitli taleplerde bulunmaktaydılar. Bu taleplerin en başta geleni salgının akabinde bölgelerinde yeni tahririn yapılmasını istemeleriydi. Diğer önemli bir talep ise genelde bölgenin belli bir süreliğine kanunnâmelerdeki vergilerden muaf tutulmasıydı.

1053/1643-44 senesinde Arhos vilayetinde tâûn salgını meydana gelmiş ve salgında bu bölgede yaşayan ahalinin çoğunun öldüğü anlaşılmaktadır. Merkeze yazılan arzlar neticesinde Mehmed Sezai Efendi bölgede yeniden tahrir işlemi yapmak için görevlendirilmiştir. Tahrir neticesinde yeni vergi mükellefiyetleri belirlenerek sorun çözülmüştür ${ }^{62}$. Aynı şekilde 21 Şaban 1070/2 Mayıs 1660'ta Göynük Kazası'nda meydana gelen tâundan ahalinin bir kısmının vefat ettiği ve bir kısmınında korkuyla başka bölgelere göç ettiği anlaşılmaktadır. Merkeze yazılan arzda ise vergilerin tenzil edilmesi için talepte bulunulmuştur ${ }^{63}$.

Merkezi idare bazen çözüm olarak bölgedeki ahalinini tamamını değil sadece hastalıktan ölenleri vergi defterlerinden düşürmüştür. 28 Rabîu'l-âhir 1027/24 Nisan 1618'de Bursa'da Kite kazasında zuhur eden tâûn illetinden 160 hristiyan neferden 73 kişin taundan öldüğüne dair Bursa ve Kite kadılarının hüccet yazdığ 1 görülmektedir. Ölen ahalinin cizye defterlerinden düşürülmesi için talepte bulunulmuştur. Yapılan tahkikatlar neticesinde ölenlerin tamamı cizye defterinden düşülmüştür ${ }^{64}$. Aynı şekilde Eğriboz Adası'nda üç sene devam eden salgından ötürü gayrimüsli halkın öldüğü ve göç ettiği yazışmalardan anlaşılmaktadır. İdareciler tarafından merkeze yazılan arzlarda gayrimüslim vergi mükelleflerinin yeniden tespiti amacıyla tahrir yapılması talep edilmiştir. Ancak merkez tarafından bir talimat gelince vergi görevlilerinin bölgeyle alakalı ağır vergilerden vazgeçtiği görülmektedir ${ }^{65}$. 18 Recep 1058/8 Ağustos 1648'de Kesendire'de tâûn meydana geldiği görülmektedir. Kesendire ahalisi vakfa ödemekte oldukları aidatların düşürülmesi için talepte bulunmuş ve talepleri Sultan İbrahim tarafindan kabul edilerek aidatların düşürülmesine dair hatt-1 hümayun verilmiştir ${ }^{66}$.

Bazı durumlarda da farklı olarak vergilerde muafiyet değil sadece indirim yapıldığı görülmektedir. 18 Zi'l-kâde 1059/23 Kasım 1649'da Eskihisar'da tâûn salgını meydana geldiğinde kadı Süleyman Efendi merkeze gönderdiği arzda yöre ahalisinin tâûn dolayısıyla sürsat zahiresinden muzdarip olduğunu kısmen indirim yapılmasını talep etmiştir. Yapılan tahkikatlar neticesinde yöreyle alakalı

\footnotetext{
62 BOA, MAD.d, 15948, 1053/1643-1644.

${ }^{63}$ BOA, C, SH, 25/1204, 1070 S. 21/2 Mayis 1660.

${ }^{64}$ BOA, TSMA, e, 770/17, 1027 R. 28/24 Nisan 1618.

${ }^{65}$ BOA, AE, SMMD. IV, 83/9828.

${ }^{66}$ BOA, TSMA, e, 798/49, 1058 B.18/8 Ağustos 1648.
} 
olan vergilerden kısmen indirim yapılmıştır ${ }^{67}$. Aynı neviden tedbirlerin 1071/1660-61'de Üsküp ve Selanik havalisinde meydana gelen veba salgınından sonra da alındığını görmekteydiz. Salgın nedeniyle etkilenen halk avarız vergisinden muaf tutulmuştur. Ancak sürsat bedelinden muaf olmamışlardır ${ }^{68}$.

18 Şevval 1106/1 Haziran 1695'te Bolu Sancağına tabi Zerzen Kazasında tâûn salgınından halkın ekserisi vefat ettiğinden tekâlifi mirîyelerden muaf tutulmuşlardır ${ }^{69}$. Aynı şekilde 1109/1697-98'de Yanbolu havalisinde meydana gelen salgından dolayı yine ahali tekâlifi mirîyeyi ödemeye iktidar olamadığına dair Yanbolu Kadısı Osman tarafından merkeze arzlar yazılmıştır ${ }^{70}$. 17. yüzyıl bu şekilde memleketin her tarafindan salgın hastalıkların meydana geldiği yazışmalardan anlaşılmaktadır. Devlet bölgeye ve salgının boyutuna göre bazen vergilerden muaf tutmuştur, bazen yeniden tahrir yaparak hayatta kalanların vergilerini tahsil etmeye devam etmiştir. Kısmen de mevcut vergilerden indirime gidilmiştir. Salgının olduğu bölgelerde en önemli sorun genel manada vergi sorunu olmaktaydı. Çünkü salgınla beraber yapılan üretim durma noktasına gelmekte ve ahali ödemekle mükellef olduğu çeşitli tekâlifleri ödeyememekteydi. $\mathrm{Bu}$ durum karşısında bölgede bulunan görevliler ahalinin talepleri doğrultusunda merkeze mevcut sorunların çözümü adına arzlar göndermekteydi. Merkezî idarede bu şekilde gelen arzların tamamına cevap vererek çözüme kavuşturma uğraşında olmuştur.

\subsection{Salgınlar Akabinde Meydana Gelen Göçler}

Tarih boyunca insan toplulukları salgın hastalıkların zuhur ettiği bölgelerden kurtulmanın en önemli yolunun salgının olduğu yerden göç etmek olduğunu görmüşlerdir. Dolayısıyla salgının başlamasıyla beraber birçok kez insanlar göç yolunu tutmuşlardır. Osmanlı Devleti'nde de 17. yüzyılda özelliklede son yıllarında devletin farklı birçok noktasında salgınların olduğu görülmektedir. Tabi salgınların artmasında ülkenin içinde bulunduğu durum da etkili olmuştur. Osmanlı Devleti'nde 1683'te başlayan Kutsal İttifak savaşları 1699'a kadar aralıklı da olsa devam etmiş̧ir. Ayrıca devlet içerisinde meydana gelen isyanlar ve merkezî otoritenin kısmen zayıf olması bu salgınları tetiklemiştir. Salgının zuhur ettiği topraklarda ahali göç etmenin yollarını aramıştır.

\footnotetext{
${ }^{67}$ BOA, TSMA, e, 522/15, 1059 Zâ. 18/23 Kasım 1649.

${ }^{68}$ BOA, MAD.d, 14680, 1071/1660-1661.

${ }^{69}$ BOA, İE, DH, 15/1381, 1106 L.18/1 Haziran 1695.

${ }^{70}$ BOA, İE, SH, 2/125, 1109/1697-1698.
} 
Evliya Çelebi, Osmanlı topraklarındaki seyahati sırasında pek çok kez salgın hastalıklarla karşılaştığını belirtmektedir. 1652'nin sonlarında Sofya'da bulunana Evliya Çelebi burada tâûn salgınından bahsederek ; "Tanrı'nın hikmeti günden güne veba şehir içinde yayılmaya başladl. Bir ay sürdü ve her gün beşer yüz insan ölürdü. Ta bu derece ilerledi ki nice bin adam Sofya'dan kaçıp diğer beldelere gittiler" ş̧eklinde insanların tâûn illetinden kaçıp göç ettiklerini kaydetmiştir ${ }^{71}$.

29 Şaban 1061/17 Ağustos 1651'de Lofça'da meydana gelen veba'dan ötürü ahalinin başka mahallere dağılmış olduğunu, göçler neticesinde geriye ahalinin 1/3'nin kaldığ1 yine dönemin yazışmalarından anlaşılmaktadır ${ }^{72} .11$ Cemâziye'l-âhir 1065/18 Nisan 1655 'te Erzurum'da salgın hastalığın olduğu görülmektedir. Yaşanan salgın afeti nedeniyle ahalinin göç ettiği ve köylerin kısmen harap hale geldiği belirtilmektedir ${ }^{73} .7$ Cemâziye'l-evvel 1070/20 Ocak 1660 'ta Üsküp'te bir tâûn salgını meydana geldiği görülmektedir. Hastalık nedeniyle ahalinin yöreden firar ettiği vurgulanmıştır. Yapılan tahkikatlar neticesinde 56 hanenin firar ederek göç ettiği tespit edilmiştir. Üsküp Kadısı tarafindan merkeze gönderilen arzda vergilerin tenzili için talepte bulunulmuştur ${ }^{74} .21$ Şaban 1070/2 Mayıs 1660'ta Göynük Kazasın'da tâûn zuhur ettiği ve salgından ötürü halkın bir kısmı vefat etmiş, diğer bir kısmı da salgın korkusuyla başka diyarlara göç etmiştir. Göynük'e tabi Boyalıca Köyü'nde bu şekilde sadece üç kişi köyde kalmıştır ${ }^{75}$.

Evliya Çelebi, 1668 'de Tirhala Sancağı'na bağlı Fenerâbâd Nahiyesi'ne uğradığında halkın tâûn yüzünden evlerini terk edip eşyalarını dahi yanlarına almadan bırakıp kaçtıklarını söylemektedir ${ }^{76}$. 1091/ 160-81'de Biga Sancağı'nda ve Çan Kazası'nda zuhur eden vebadan ahalinin bir kısmı vefat etmiş, bir kısmı da korkuyla göç etmiştir. Biga Kadısı Hızır ve Zekeriya tarafından yazılan arizada yeniden nüfus tahriri yapılması talep edilmiştir ${ }^{77}$. Yine 29 Zi'l-hicce 1110/28 Haziran 1699'da Kemer-i Edremit ve havalisinde veba salgını meydana geldiği görülmektedir. Hastalıktan yöre ahalisinin çoğunluğu perakende ve perişan olmuştur. Bazı ahalinin ise başka bölgelere göç ettiği görülmektedir. Alınan karar

\footnotetext{
${ }^{71}$ Bkz. Evliya Çelebi, Seyehatnâme, c. 3, 531.

72 BOA, TSMA, d, 9655/6-7,1061 Ş. 29/17 Ağustos 1651.

${ }^{73}$ BOA, MAD.d, 14739, 1065 C. 11/18 Nisan 1655.

${ }^{74}$ BOA, MAD.d, 14680, 1070 Câ. 7/20 Ocak 1660.

${ }^{75}$ BOA, C, SH, 25/1204, 1070 Ş. 21/2 Mayıs 1660.

${ }^{76}$ Kılıç, "16-18. Yüzyıllarda Balkan Şehirlerinde Yaşanan Veba Salgınları ve Sosyo-Ekonomik Etkileri". c. 3, 1191.

${ }^{77}$ BOA, İE, DH, 3/262, 1091/1680-1681.
} 
gereği Edremit ve ona bağlı köylerde yeniden tahrir işleminin yapılması yöredeki görevlilere bildirilmiştir ${ }^{78}$.

Tâûn/veba salgınlarının yaşandığı bölgelerde sağ kalan insanlar özellikle salgına yakalanmamak için bulundukları yerleri terk etmeyi uygun bulmuşlardır. Dönemin şartları göz önüne alındığında tedavi imkânlarının kıtlığı, tıbbi gelişmelerin yeterli düzeyde olmaması ve temizlik problemleri salgınların kısa sürede yayılmasını tetiklemiştir. Dolayısıyla en mantıklı görünen seçeneğin göç etmek olduğu anlaşılmaktadır. Ancak bu tarz bir çözüm devlet için önemli sorun teşkil etmekteydi. Nitekim böyle bir durumda vergi tahsil etme noktasında görevliler sıkıntılar yaşamıştır. Malum durumun derhal merkeze bildirilmesi uygun görülmüștür. Merkezde alınan kararlar gereği bölge halkının vergiden muaf tutulması, vergilerden kısmi indirime gidilmesi veya vergilerin ertelenmesi gibi seçenekler olmaktaydı. Ancak hangi çözüm olursa olsun devlet hazinesi ve toplumsal düzen için bu salgınlar büyük kayıp sayılmaktaydı. Meydana gelen salgın hastalık devletin iskân coğrafyasını, ekonomik yapısını ve sosyal hayatını önemli derecede etkilemekteydi.

\section{SONUÇ}

Salgın hastalıklar, meydana gelen çeşitli doğal afetler gibi insanları, toplumları ve devletleri birçok yönden etkisi altına almıştır. Bulaşıcı olan salgınlardan korunma ve tedavilerinin keşfedilmesi uzun zaman almıştır. Meydana gelen salgın hastalıklar geride toplu ölümler ve perişan kalan kitleler bırakmıştır. Osmanlı Devleti'nde de 16. yüzyıldan itibaren salgın hastalıkların meydana geldiği ve bu hastalıkların 17 . yüzyılda daha da arttığı dönemin kaynaklarından anlaşılmaktadır. Salgın hastalıkların içinde en etkili ve yaygın olanı ise tâûn/veba olmuştur. Salgın hastalıklar zuhur ettiği yörede siyasî, askerî, sosyol, ekonomik ve kültürel alanlarda olumsuz etki bırakmıştır.

Salgın hastalıklar yüzünden ölen insanlar vergi mükellefi olduklarından devletin vergi gelirlerinde önemli düşüşler görülmüştür. Bu durum hastalıkların ekonomik yönden olumsuz etkilerini gösterir. Bunun yanında insanların salgının yayıldığ 1 bölgelerden göç etmesi de ekonomiyi olumsuz etkilemiştir. Meydana gelen göçler neticesinde tarımsal faaliyetler aksamaya başlamıştır. Tarım toplumu olan Osmanlı Devleti bu durumdan büyük ölçüde etkilenmiştir. Dolayısıyla salgın ve bulaşıcı hastalıklar her nerede ortaya çıkmışsa, o yörede önemli ölçüde iktisadî buhranlara neden olmuştur. Salgınlar neticesinde ortaya çıkan göçler birtakım toplumsal sorunları da beraberinde getirmiştir. Salgının

${ }^{78}$ BOA, AE, SMST. II, 4/350, 1110 Z. 29/28 Haziran 1699. 
verdiği endişe ve kaygıyla toplumsal düzen bozulmuştur. Göçlerle birlikte üretim sekteye uğramış, yer yer kıtlıklar görülmüştür.

Salgının meydana geldiği bölgelerin idarecileri salgınla alakalı merkeze çeşitli taleplerini dile getiren arzlar göndermiştir. Merkezî idare mümkün şekilde salgın bölgelerine kolaylıklar sağlamaya çalışmıştır. Bu kolaylıklar bazı dönemlerde vergilerden muaf tutma, mevcut vergilerden indirime gitme veya yeniden tahrir yaparak geriye kalan vergi mükellefini tespit etmeye çalışma şeklinde vuku bulmuştur.

\section{KAYNAKÇA / REFERENCES}

\section{Arşiv Kaynakları / Primary Sources}

Başbakanlık Osmanlı Arşivi, BOA

A.DVN.MHM.d. 79. 102.

MAD.d. 14680. 14739. 15633. 15948.

İE. SH. 2/134. 1/53. 2/120. 1/100. 2/122. 2/136. 2/124. 2/125. 2/137. 2/127. 2/119. 2/105. 2/159.

İE. DH. 3/262. 1/1381-1385. 18/1723. 12/1177. 16/1521. 15/1381. 3/.262.

C. SH. $25 / 1204$.

AE. SMMD. IV. 83/9828. SMST. II. 4/350.

Topkapı Sarayı Müzesi Arşivi, TSMA

TSMA. d. 1306/63. 1341/2. 1341/1. 9655/6-7.

TSMA. e, 6841/4-9. 770/17. 798/49. 522/15.

\section{Araştırma ve İnceleme Eserler}

Ağır, S. (2020). Osmanlı'da Karantina Uygulama Süreçleri ve Tepkiler (18651914). Yayınlanmamış yüksek lisans tezi, Hacettepe Üniversitesi Sosyal Bilimler Enstitüsü.

Arıkan, Z. (2011). Jean Baptiste Tavernier. Türkiye Diyanet Vakfi İslam Ansiklopedisi içinde (Cilt. 40, s.181-183), Diyanet Vakfı yayınları.

Ayar, M. (2007). Osmanlı Devleti'nde Kolera İstanbul Örneği (1892-1895). Kitabevi yayınları. 
Bargrave, R. (1999). The Travel Diary of Robert Bargrave (Levant Mercant 1647-1656). (M. G.Brennan. Haz.). The Hakluyt Society.

Başbakanlık Devlet Arşivleri Genel Müdürlüğü. (2017). Osmanlıda Yer Adları. Başbakanlık Devlet Arşivleri Genel Müdürlüğü yayını.

Batğı, Ö. (2017). Seyahatnamelerde Osmanlı insanının hastalıkları ve tedavi yöntemleri. Osmanlı Mirası Araştırmaları Dergisi (OMAD), 4(8), 169182.

Çalışkan, A. \& Eyicil A. (2019). XVIII. ve XIX. Yüzyılda Halep ve civarında salgın hastalıklar. Bingöl Üniversitesi Sosyal Bilimler Enstitüsü Dergisi, 9(18), 1289-1319.

Çelebi, E. (2006). Seyahatname (Cilt 1-12). (S. A. Kahraman-Y. Dağl1. Haz.) Yap1 Kredi yayınları.

Dinç, G. (2012). Bulaşıcı ve salgın hastalıklar tarihine genel bir bakış. İ. BaşoğluG. Dinç (Ed.), Yeni Tıp Tarihi Araştırmaları Dergisi, 18, 43-72.

Dinç, G. (2012). Ortaasya Türk topluluklarından günümüz Türkiyesine bulaşıc1 ve salgın hastalıkların gelişimi. İ. Başoğlu-G. Dinç (Ed.), Yeni Tıp Tarihi Araştırmaları Dergisi, 18, 73-104.

Ertaş, M. Y. \& Eğnim, K. (2011). Evliya Çelebi Seyahatnamesi'nde hastalıklar, Pamukkale Üniversitesi Sosyal Bilimler Enstitüsü Dergisi, 10, 83-107.

İşbilir, Ö. (2007). "Nüzül”. Türkiye Diyanet Vakfi İslam Ansiklopedisi içinde (Cilt. 33, s. 311-312). Diyanet Vakfı yayınları.

Kılıç, O. (2004). Eskiçă̆dan Yakınçă̆a Genel Hatlarıyla Dünyada ve Osmanlı Devleti 'nde Salgın Hastalıklar. F1rat Üniversitesi Orta-Doğu Araştırmaları Merkezi yayınları.

Kılıç, O. (2016). 16-18. Yüzyıllarda Balkan Şehirlerinde Yaşanan Veba Salgınları ve sosyo-ekonomik etkileri. Z. Gölen-A. Temizer (Ed.), Osmanlı Dönemi Balkan Şehirleri içinde (Cilt. 3, s. 1181-1210), Gece Kitaplı̆̆1 yayinlar1.

Kılıç, O. (2019). Salgın hastalıkların Osmanlı Vergi Düzenine Etkisi. Üçüncü Iktisat Tarihi Kongresi bildirileri içinde (ss. 371-384).

Naîmâ Mustafa Efendi, (2007). Târih-i Na'îmâ (Cilt 1-4). (M. İpşirli. Haz.). Türk Tarih Kurumu yayınları. 
17. Yüzyılda Osmanlı Devleti’nde Meydana Gelen Salgın Hastalıklar...

Özden, K. \& Özmat, M. (2014). Salgın ve Kent: 1347 veba salgınının Avrupa’da sosyal, politik ve ekonomik sonuçları. İdeal Kent Araştırmaları Dergisi, $12,60-87$.

Pakalın, M. Z. (1993). Osmanlı Tarih Deyimleri ve Terimleri Sözlüğü (Cilt 1-3). Milli Eğitim Bakanlığı yayınları.

Panzac, D. (1997). Osmanlı Imparatorluğu’nda Veba (1700-1850) (S. Y1lmaz, Çev.). Tarih Vakfı Yurt yayınları.

Sarıcaoğlu, F. (2004). Melek Ahmed Paşa. Türkiye Diyanet Vakfi İslam Ansiklopedisi içinde (Cilt. 29, s. 42-44). Diyanet Vakfı yayınları.

Sarıyıldı, G. (1996). Hicaz Karantina Teşkilatı (1865-1914). Türk Tarih Kurumu yayınları

Sezen, T. (2017). Osmanlı Yer Adları. Başbakanlık Devlet Arşivleri Genel Müdürlüğ̈̈ Yayını.

Sertoğlu, M. (2015). Osmanlı Tarih Lugatı. Kurtuba kitapları.

Tavernier, J. B. (2007). 17. Yüzyılda Topkapı Sarayı. (T. Tunçdoğan, Çev.). Kitap yayınlar1

Thevenot, J. (2014). Jean Thevenot Seyahatnamesi. (A. Berktay. Çev.). Kitap yayınevi.

Varlık, N. (2011). Tâûn. Türkiye Diyanet Vakfi Íslam Ansiklopedisi içinde (Cilt. 40, s. 175-177). Diyanet Vakf1 yayınları.

\section{EXTENDED ABSTRACT}

Throughout the history of humanity, diseases were one of the problems that societies had to deal with. The diseases that transformed into pandemics had impacted societies significantly throughout history. Together with increasing interaction between societies, the rate of spread also increased. The pandemics caused mass deaths, were not immediately curable, and are seen as important factors that changed the course of history. These pandemics negatively impacted states and societies across the world with respect to their economic, military, social, and political well-being. Pandemics spread fast in a short amount of time and led to death of thousands and sometimes millions of people. As a result of the pandemics, some states were either weakened or collapsed not because of wars or enemy soldiers but because of diseases. Pandemics left deep marks 
behind by influencing social culture, lifestyle, art, literature, and even the daily language.

The Ottoman Empire which ruled over vast territories for a long time was also affected from pandemics many times and fought against them. The situation was even worsened due to the particular geostrategic location of the Empire which was at the crossroad of important trade routes. In case of the Ottoman Empire, plague appears to be the most harmful contagious disease that gained a place in collective memory. Plague is the first disease that comes to mind when someone speaks of pandemics in the Ottoman Empire. It is referred as "tâûn" in Ottoman resources and among people. Because of its geographical position, the Ottoman Empire was exposed to several plagues for centuries. İstanbul, İzmir, Thessalonica, Aleppo, Alexandria, and Cairo are the Ottoman provinces that were most heavily impacted from the plagues.

Pandemics of the 17th century had significant economic, political, and geographical influence on societies that cannot be ignored. As can be observed through different centuries, pandemics occurred in different locations and caused challenges to the state in this century as well. The Ottoman society was exposed to pandemics especially through traders who are constantly on move and pilgrims who have to travel. Furthermore, the mass migrations and increasing poverty caused by the policitical and economic depression and lost wars increased the spread of contagious diseases. Increasing prevalence of contagious diseases in this century caused several problems. An important problem in the 17th century appears to be the taxation issue which was caused by the death of thousands of people in the center of disease.

Taxation was an important source of revenue that sustained the state instutitons in the Ottoman Empire like it did for every other states in the world. In the Ottoman taxation system, every subject was a taxpayer. The collected taxes were transferred to the central revenue. Therefore, pandemics decreased the state's tax revenues significantly. Decreasing taxation caused various setbacks in terms of payments. Due to the deaths caused by pandemics, local people were not able to pay full amount of their taxes and sometimes could not pay them at all. These crises caused states to experience economic distress which triggered military, social, and political problems.

One of the biggest problems was the migrations triggered by the pandemics. In the 17th century, especially in its last quarter, there were pandemics at different locations of the state. The conditions that states had also had an impcat on state of pandemics. The Holy Alliance Wars started in 1683 and periodically continued until 1699. In addition, rebellions and the weakening central authority triggered 
the pandemics. People searched ways to leave the pandemic-ridden lands. People who survived the plague-ridden lands wanted to migrate to stay away from the disease. Given the conditions of the period, the limited access to treatment, problems with sanitation, and insufficient medical expertise and technology caused spread of pandemics. Therefore, migration became a viable option to societies.

The Ottoman Empire implemented tax exemptions to the regions that were influenced from pandemics in order to minimize migration and prevent the possible problems regarding the public good provision. In this century, the regional governors made specific demands in their communication with the central government. One of the most raised issues was to conduct a new census in the post-pandemic period. Another important demand was asking for an exemption from taxation at least for a certain period. These correspondences give important information on the pandemics in the 17th century. The state implemented tax exemptions depending on the scale of pandemic and conducted censuses to extract taxes from those who survived. Partly, it also decreased the taxation rates. No matter what, both the state revenue and the social order were negatively impacted from the pandemics. These pandemics singificanly affected state's settlement geography, economic structure, and social life. By looking at the pandemics occurred in the 17th century, this study analyzes the destructions they caused in state and society. In addition, economic problems and migration movements caused by the pandemics will be analyzed as well. 